\title{
Corporate Governance and Stock Price Crashes
}

Panayiotis C. Andreou, Constantinos Antoniou, Joanne Horton and Christodoulos Louca ${ }^{1}$

This version: March 2012

[Preliminary Version]

\begin{abstract}
We investigate whether firms with strong corporate governance exhibit lower firm-specific future stock price crashes. Results show that ownership structure, accounting opacity, as well as board structure and processes influence future crashes. These findings are more pronounced for firms that operate in less competitive industries and those with higher returns uncertainty. Further investigation of the responsiveness of crashes to changes in the corporate governance measures highlights that changes in ownership structure and CEO incentives are associated with significant changes in future crashes.
\end{abstract}

\footnotetext{
${ }^{1}$ Andreou and Louca are from the Cyprus University of Technology, Department of Commerce, Finance and Shipping, and Visiting Research Fellows at Durham Business School. Antoniou and Horton are from Exeter University Business School, U.K. Emails: panayiotis.andreou@cut.ac.cy, c.antoniou@exeter.ac.uk, J.Horton@exeter.ac.uk and christodoulos.louca@cut.ac.uk. We thank Richard Harris, Rajesh Tharyan, Grzegorz Trojanowksi and seminar participants at Exeter Business School for useful comments and suggestions. All remaining errors are our own.
} 


\title{
Corporate Governance and Stock Price Crashes
}

\author{
This version: March 2012 \\ [Preliminary Version]
}

\begin{abstract}
We investigate whether firms with strong corporate governance exhibit lower firm-specific future stock price crashes. Results show that ownership structure, accounting opacity, as well as board structure and processes influence future crashes. These findings are more pronounced for firms that operate in less competitive industries and those with higher returns uncertainty. Further investigation of the responsiveness of crashes to changes in the corporate governance measures highlights that changes in ownership structure and CEO incentives are associated with significant changes in future crashes.
\end{abstract}




\section{Introduction}

In the absence of optimal contracts managers can exploit their informational advantage and engage in opportunistic behaviour to safeguard their own interests at the expense of long-run shareholders. Broadly, such opportunistic (and suboptimal) behaviour can take two forms: managers may undertake investment decisions to temporarily boost valuations, or they may engage in earnings management hoarding of bad news, to preserve an inflated stock price. These suboptimal practices, however, can lead to significant stock price crashes in the future (henceforth crashes) when the fundamentals are finally revealed.

Agency theory suggests that effective corporate governance mechanisms curb such sub-optimal decision making by managers. Firstly, by reducing the information asymmetry between them and their shareholders [Karamanou and Vafeas (2005)], making such behaviour more difficult from the outset. Secondly, by obstructing earnings management and thus the hoarding of bad news [Xie, Davidson III and DaDalt (2003)], and by preventing suboptimal investment decisions [Masulis, Wang and Xie (2007)]. In this study we build on this research and examine whether firms with stronger corporate governance mechanisms exhibit relatively lower future stock price crashes.

In our analysis, we consider four dimensions of governance, namely ownership structure, accounting opacity, board structure and processes, and CEO incentives and power. Our findings reveal several important patterns. We find that crashes are positively related to institutional ownership and directors' stock ownership, which suggests that, in these cases, stock ownership encourages suboptimal practices. Moreover, crashes are positively related to the opacity of financial reports, highlighting that suboptimal decision making mainly occur in less transparent environments. With respect to board structure, the percentage of independent directors on the audit committee and auditor industry expertise are negatively related to crashes, consistent with the view that they improve the reliability of a financial reporting. 
We also conduct analysis to explore whether specific industry or company characteristics that theoretically can affect the importance of corporate governance, influence the aforementioned relationships. Our findings show that the impact of governance on crashes are stronger when the company operates in a low competition industry (where the market is less able to punish suboptimal managerial behaviour), and is solely concentrated in companies with higher returns uncertainty, where it is easier for managers to mask price maximisation as long run value maximisation.

Finally, we use a dynamic, changes-based model to examine the responsiveness of stock price crashes to changes in the corporate governance measures. We find that an increase in accounting opaqueness and institutional ownership increases crashes. Interestingly, we find that increases in blockholders reduce crashes. This conflicting result between institutional ownership and blockholders highlights the relative differences in the time horizons of these two types of investors [Bushee (2001)]. In addition, contrary to the levels model, we find that increases in CEO compensation (bonus and stock/option awards) lead to increases in future crashes. This result suggests that increases to performance-based compensation encourage price maximization, increasing stock price crashes.

This study contributes to the literature that highlights the economic significance of corporate governance systems. Several studies have highlighted the effect of corporate governance on average returns [Gompers, Ishii and Metrick (2003); Core, Guay and Rusticus (2006); Masulis, Wang and Xie (2007)]. Chung, Elder and Kim (2010) provide evidence that better governance systems improve liquidity, another important economic property of assets that entail uncertainty. In this study we broaden the economic implications of corporate governance by examining its relationship with (large) negative stock price movements.

This evidence is of particular interest to investors who wish to take long run positions in the stock market. Prospect theory postulates that the effect of losses, as opposed to gains, is 
disproportionately larger [Kahneman and Tversky (1979)]. The survey studies by Koonce, McAnnaly and Mercer (2005) and Olsen (1997), which show that investors rank the probability of a large loss as the primary source of investment risk, suggest that crashes are a first order concern for investors. Therefore, evidence on the predictability of crashes are of vital importance, especially since it cannot be diversified away (Sunder, 2010). Along these lines Kim, Li and Zhang (2011) show that CFO option holdings increase crashes and Kim and Zhang (2010) show that accounting conservatism reduces it. Our findings extend this literature and highlight that investors should screen firms on the basis of their corporate governance systems to reduce their exposure to crashes.

The paper proceeds as follows. Section 2 discusses the relevant literature and develops the motivation for the study. Section 3 describes variable measurements. Section 4 discusses sample construction and descriptive statistics. Section 5 presents empirical results. Finally, Section 6 describes the study's conclusions.

\section{Literature review and motivation}

Self-interested managers may pursue short-term, opportunistic practices that are suboptimal for their long run shareholders. Such sub-optimal practices often take the form of unbeneficial investment decisions. As explained by Bebchuk and Stole (1993) and Baker, Ruback and Wurgler (2004), in less than fully rational markets, managers have the incentive to "cater" to prevailing sentiment and invest in projects that are overvalued by the market. ${ }^{2}$ This catering hypothesis is supported by prior evidence that demonstrates that (i) managers overinvest in fixed assets during periods of inflated performance [McNichols and Stubben (2008)], (ii) firms hire and invest excessively when earnings are overstated [Kedia and Philippon (2009)], and (iii) discretionary accruals and firm investment are positively related

\footnotetext{
${ }^{2}$ For example during the stock market boom in the late nineties the number of tech IPO's surged. This is because the market was overly optimistic about the capacity of the internet to generate growth, and viewed these projects favourably. Therefore, managers catered to this demand.
} 
[Polk and Sapienza (2009)]. Overall, such suboptimal investment policies project strong investment opportunities in the short-term, leading however to undercapitalization and stock price crashes when the actual growth rate is revealed [Benmelech, Kandel and Veronesi, 2010].

Manager's opportunistic behavior is not only limited to investments. To support the pretense of strong growth opportunities, managers can also manipulate financial information, engaging in the well-known practice of earnings management. Kothari et al. (2009) argue that managers have incentives to stockpile negative information from the market for financial reasons, such as career and compensation concerns. Similarly, Ball (2001) suggests that nonfinancial reasons, such as empire building and maintenance of self esteem may also provide managers the incentives to withhold bad news. Hoarding bad news for an extended period of time, however, is unsustainable [Bleck and Liu (2007)]. As a result, when all the hitherto negative information is revealed in the market, results in large negative price jumps, that is, stock price crashes [Jin and Myers (2006), Hutton et al. (2009)].

A prerequisite for the aforementioned suboptimal managerial behaviors is the market inability to perfectly detect and assess such managerial actions. Stein (1988) suggests that even an efficient market populated by rational investors may not be able to detect suboptimal managerial behavior when the shareholders are exposed to high agency risk.

A considerable body of academic literature, however, suggests that sound corporate governance systems helps to alleviate agency risk problems because it bridges the information asymmetry gap between shareholders and managers [Shleifer and Vishny (1997), Healy et al. (1999), Karamanou and Vafeas (2005), Armstrong, Balakrishnan, and Cohen (2012)].

We extend these findings by considering the relationship between the quality of firms' corporate governance systems and their stock price crashes. We hypothesize that strong 
corporate quality governance systems reduce agency conflicts between managers and shareholders and provide independent monitoring on managerial decisions. Therefore, they limit short-run price maximization (through either overinvestment or earnings management) reducing future stock price crashes.

In a contemporaneous study, Callen and Fang (2011) show that institutional ownership increases crashes. In addition, Hutton et al (2009) show that accounting opaqueness increases crashes. We confirm these findings in our analysis. However, because we take a broader view of the issue, we highlight more aspects of corporate governance that affect crashes. In addition, we conduct additional analysis examining whether specific industry and firm characteristics that theoretically can affect the importance of corporate governance, play a moderating role. Indeed, we find that effect of governance on crashes (including the relationships documented by Callen and Fang (2011) and Hutton et al (2009) depends on such characteristics. Finally, we use a dynamic, changes based-model to examine the responsiveness of crashes on in the various corporate governance measures. Such an approach allows us to better conceptualize whether crashes do not only associate with corporate governance mechanisms in the cross-section, but also associate with changes in governances over time.

\section{Variable Measurement}

\subsection{Measurement of firm-specific crashes}

We are interested to investigate the impact of firm-specific governance on firmspecific crashes. Therefore, we estimate firm-specific weekly returns using the following expanded index model regression:

$$
r_{j, t}=\alpha_{j}+\beta_{1, j} r_{m, t-2}+\beta_{2, j} r_{m, t-1}+\beta_{3, j} r_{m, t}+\beta_{4, j} r_{m, t+1}+\beta_{5, j} r_{m, t+2}+\varepsilon_{j, t}
$$


where $r_{j, t}$ is the return on stock $\mathrm{j}$ in week $\mathrm{t}$ and $r_{m, t}$ is the CRSP value-weighted market index in week t. To allow for non-synchronous trading we include lead and lag variables for the market index (Dimson, 1979). This regression removes market-wide return movements from firm returns, and thus residuals capture weakly firm-specific returns. Since residuals from equation (1) are skewed, we define firm-specific weekly return for firm $j$ in week $t\left(W_{j, t}\right)$ as the natural logarithm of one plus the residual (i.e., $W_{j, t}=\ln \left[1+\varepsilon_{j, t}\right]$ ). Then, following Chen, Hong and Stein (2001), Hutton et al. (2009), Bradshaw, Hutton, Marcus and Tehranian (2011), and Kim et al. (2011) we employ two primary measures of crashes. The first measure is the negative conditional skewness (NCSKEW). NCSKEW is the negative of the third moment of firm-specific weekly returns for each firm and year divided by the standard deviation of firm-specific weekly returns raised to the third power. Specifically, for a given firm in a fiscal year we calculate $N C S K E W$ as follows:

$$
N C S K E W_{j, t}=-\left[n(n-1)^{\frac{3}{2}} \sum W_{j, t}^{3} /\left[\left(n-1 \_(n-2)\left(\sum W_{j, t}^{2}\right)^{\frac{3}{2}} .\right.\right.\right.
$$

The second measure is the extreme sigma (EXTR_SIGMA). EXTR_SIGMA is the negative of the worst deviation of firm-specific weekly returns from the average firm-specific weekly return divided by the standard deviation of firm-specific weekly returns. Particularly, for a given firm in a fiscal year we compute EXTR_SIGMA as follows:

$$
E X T R \_S I G M A=-\operatorname{Min}\left[\frac{W-\bar{W}}{\sigma_{W}}\right],
$$

where $\bar{W}$ is the mean of the firm-specific weekly return and $\sigma_{W}$ is the standard deviation of the firm-specific weekly return. Larger values of NCSKEW and EXTR_SIGMA signify greater crashes.

Though not tabulated, our baseline results are qualitatively similar using two alternative measures of crashes. First, we define an indicator variable $(C R A S H)$ that equals 
one when a firm experiences at least one crash week during the fiscal year, and zero otherwise. A crash week is when a firm experiences firm-specific weekly returns 3.2 standard deviations ( 3.2 is chosen to generate a frequency of $0.1 \%$ in the normal distribution) below the mean firm-specific weekly returns for the entire fiscal year. Second, following Chen, Hong, and Stein (2001) we compute the down-to-up volatility (DUVOL). DUVOL is calculated as follows: For each firm $j$ over a fiscal year $t$, we separate all the weeks with firmspecific returns below the annual mean and call them as "down weeks" from those firmspecific weekly returns which are above the mean called them as the "up weeks". We then compute the standard deviation for the two predefined subsamples. DUVOL is the log of the ratio of the standard deviations of the two subsamples, the one for the "down weeks" over the standard deviation of the "up weeks". These results are available from the authors upon request.

\subsection{Corporate Governance}

Our study examines how a comprehensive set of variables that captures different aspects of the governance relates to crashes. In particular, following previous governance literature, we use variables that measure four different attributes of the governance system: (i) ownership structure, (ii) accounting opacity, (iii) board structure and processes, and (iv) CEO incentives and power.

\subsubsection{Ownership structure}

A considerable body of literature investigates the role of shareholders with significant firm ownership in protecting all shareholders' interest from self-serving managerial behaviour. Shleifer and Vishny (1997) argue that shareholders with significant ownership positions have the financial interest and ability to evaluate investment decisions and corporate policies. Therefore, when necessary, they can exert pressure using their voting power to avoid suboptimal investment decisions. In an insightful study, Edmans (2009) highlights that the 
presence of institutional investors, who have the ability to trade on information about long run value, shields managers from temporary earnings disappointments allowing them to maintain a long run perspective. This is known as the monitoring function of institutional investors. Consistent with this notion of monitoring, Shivdasani (1993) reports that the likelihood of a hostile takeover increases whenever outside blockholders are present. Similarly, Cornett, Marcus and Terhanian (2008) find that institutional investors obstruct earnings management. According to this monitoring view, the relationship between institutional ownership and stock crash should be negative.

A competing view is that large outside shareholders act as speculators as opposed to investors, being overly concerned with earnings disappointments, thus pressurizing management to meet or beat earnings expectations [Graves and Waddock 1990; Porter 1992, Bushee (1998), (2001)]. Such pressure, however, encourages short run price maximisation, and hence increases crashes. Consistent with this expropriation view, Callen and Fang (2011) find that institutional ownership increases crashes, especially when the institutions have shorter horizons.

Clearly, which of the two effects dominates depends on the horizon of the institutional investors, and is therefore an empirical issue. For this reason, we leave the relationship between institutional investors and crashes unsigned. We use two variables to measure institutional ownership: $B L O C K$ is the number of outside blockholders that own at least $5 \%$ of a firm. INST is the percentage of shares held by institutional investors. This distinction between the types of investors may also provide us with an opportunity to observe the effect of any relative differences in the time horizons of investors.

We also consider the extent of insider ownership. As insider ownership rises, insiders have incentives to protect shareholders' interest and thus would need less supervision, albeit in a non-linear fashion [Morck et al. (1988), McConnell and Servaes (1990)]. In that respect, 
such insiders would abstain from suboptimal investment decision-making and would strive to enhance information environment, possibly leading to a negative relation with future crashes. INSIDER, is the percentage of shares held by officers or directors.

Our last ownership variable concerns whether the directors that seat on the various committees own shares in the company. The traditional view is that directors that own stocks have the incentive to engage in the companies' operations more diligently [Hambrick and Jackson (2000)], which would lower crashes. Consistent with this view, Yermack (2004) finds that outside director's option incentives bear a positive relationship with future firm performance. However, there is also evidence to the contrary. For example, Core, Holthausen and Larcker (1997) find that there is no evidence to suggest that directors with stock ownership are more attentive. It is also possible that directors' compensation packages align their interests with managers, as opposed to shareholders. For example, Brick et al. (2006) find that excess director and excess CEO compensation are positively related, possibly attenuating crashes. Given the mixed evidence, we make no predictions on the sign of the relationship between board stock ownership and crashes. We use the percentage of directors that hold stock in the firm, BRD_STOCK, to capture outside director's monitoring incentives.

\subsubsection{Accounting opacity}

Accounting opacity is crucial to mitigating the information asymmetry between managers and shareholders. Better opacity facilitates the monitoring of managerial actions and thereby reduces the likelihood that managers would exhibit self-serving behavior. Sengupta (1998) argue that firms with more informative disclosures are less likely to withhold negative information. Following Hutton et al. (2009) we use the three-year moving sum of the absolute discretionary accruals (OPAQUE) as a measure of opacity in financial reports. We obtain discretionary accruals as the residuals of a modified Jones (1991) model. 
Particularly, for each year and industry membership based on Fama and French (1997) 48industry groups we estimate the following model:

$$
\frac{\text { TA }_{i, t}}{\text { Assets }_{i, t-1}}=\alpha_{1} \frac{1}{\operatorname{Assets}_{i, t-1}}+\alpha_{2} \frac{\Delta \text { Sales }_{i, t}-\Delta A R_{i, t}}{\text { Assets }_{i, t-1}}+\alpha_{3} \frac{\operatorname{PPE}_{i, t}}{\operatorname{Assets}_{i, t-1}}+\alpha_{4} \frac{\text { CFO }_{i, t}}{\operatorname{Assets}_{i, t-1}}+\varepsilon_{i, t}
$$

where total accruals $\mathrm{TA}_{\mathrm{i}, \mathrm{t}}$ is the change in current assets plus the change in debt in current liabilities and the change in income tax payable, and minus the change in cash, the change in current liabilities and depreciation amortization expenses. $\Delta$ Sales $_{\mathrm{i}, \mathrm{t}}$ is the change in sales. $\Delta \mathrm{AR}_{\mathrm{i}, \mathrm{t}}$ is the change in accounts receivables. $\mathrm{PPE}_{\mathrm{i}, \mathrm{t}}$ is the property plant and equipment. $\mathrm{CFO}_{\mathrm{i}, \mathrm{t}}$ is the cash flow from operations minus the extraordinary items. ${ }^{3}$

The reliability of a firm's financial information is responsibility of audit committee. Klein (2002), for instance, finds a negative relation between audit committee and earnings management practices. Similarly, Agrawal and Chadha (2005) find a negative relation between boards/audit committees that comprise with independent outside directors with accounting or finance background and earnings restatements. To proxy for the quality of the audit process, we use $A U D \_I N D$ defined as the percentage of outside independent directors in the audit committee. Overall, to the extent that audit committees carry out their duties effectively, managers should be less likely to exhibit self-serving behavior. Accordingly, there should be a negative relation between audit committee functioning and crashes.

Finally, as part of their overall disclosure strategy, firms may select industry-specialist audit firms. In that respect, Dunn and Mayhew (2004) posit that auditor expertise signals a firm's intention to provide enhanced disclosures. Thus, we use a measure of auditor expertise, AUD_EXP, using a dummy variable that equals one when the audit firm of a particular firm has more than a third of market share of total sales within an industry. We expect a negative relation between AUD_EXP and crashes.

\footnotetext{
${ }^{3}$ The inclusion of cash flows controls for extreme operating performance [Cohen et al. (2005)].
} 


\subsubsection{Board structure and processes}

Prior literature suggests that different facets of board structure are determinants of managerial action's monitoring. Drawing on Fama and Jensen (1983), outside directors who are independent on management's influence are useful to protect shareholders from selfserving managerial behavior [Agrawal and Chadha, 2005, Xie, Davidson III and DaDalt (2003)]. Largely the literature posits that board independence is positively related to firm performance (DeFond, Hann and $\mathrm{Hu}, 2005$, Davidson III, Xie and $\mathrm{Xu}, 2004$ ). Better firm performance should reflect better investment decisions and less information asymmetry between managers and shareholders [Beasley (1996), Klein (2002)], leading to lower crashes. A different stream of literature, however, finds no relation between board independence and measures of firm performance [Hermalin and Weisbach (1991), Bhagat and Black (2000)]. Nevertheless, we tentatively expect that a firm's board independence, measured as the percentage of outside directors serving the board, BRD_IND, is negatively related to crashes.

Among outside independent directors, more competent directors should be able to limit self-serving managerial behavior, leading to lower crashes. Similar to Klein (1998) and Ashbaugh-Skaife et al. (2006), we measure board competence by the percentage of directors that also serve on boards of other firms, BRD_COMP. We expect a negative relation between BRD_COMP and crashes.

Finally, the last measure is a process, whether the company has a formal, clearly defined corporate strategy in its mandate. This information takes the form of a dummy variable $G P O L$, that equals 1 if such a policy exists and 0 otherwise. We expect that this variable is negatively related to crashes, because in the presence of such a policy it will be more difficult for the manager to deviate and engage in opportunistic behavior. 


\subsubsection{CEO incentives and power}

Recent evidence suggests that CEOs/CFOs compensation structure may induce selfserving behavior. Healy (1985) and Bergstresser and Phillippon (2006), for instance, find that bonus plans and the sensitivity of CEOs option portfolio value to stock prices is positively related to earnings management behavior, leading to greater crashes $[\mathrm{Kim}, \mathrm{Li}$, and Zhang (2011)]. Thus, we use CEOs bonus scaled by salary, BONUS, [Fahlenbranch and Stulz (2011)], option holdings incentives ratio (INC_OPT) and stock holdings incentives ratio (INC_STC) [Bergstresser and Phillippon (2006); Kim, Li and Zhang (2011)] to measure compensation incentives. ${ }^{4}$

A CEO's influence on the board is another element of "CEO incentives and power" since it can reduce the board's effectiveness in monitoring managers. The greater the CEO's influence on the board, the less likely the board to suspect irregularities such as suboptimal investment decisions or earnings management. Imhoff (2003) suggest that CEO's that also serve as chairman of the board are more powerful since the chairman of the board set board's agenda. As measure of CEO power, we use CEO DUALITY, defined as a dummy variable that equal 1 when the positions of the CEO and the chairman of the board are held by the same person, and zero otherwise. If DUALITY enhances self-serving managerial behavior, we would expect a positive relation with crashes.

\subsection{Control variables}

In accord with prior literature we include several control variables. First, Hong and Stein (2003) model predicts that investor heterogeneity is causing greater crashes. Thus, we control for investor heterogeneity using the detrended average weekly stock trading volume

\footnotetext{
${ }^{4} \mathrm{Kim}, \mathrm{Li}$ and Zhang (2011) find strong evidence that the sensitivity of a chief financial officer (CFO) option portfolio value to stock price is positively related to crashes. We also investigate the robustness of our findings after including CFO stock and option holdings incentives. Untabulated results show that our main findings remain unaltered after including CFO incentives. In addition, we find no relation between CFO incentives and crashes. We choose to report our main analysis using only CEO incentives because including CFO incentives reduces substantially the number of firm-year observations.
} 
in year t-1 $\left(D T U R N_{t-1}\right)$. We also include past average firm-specific weekly returns $\left(R E T_{t-1}\right)$ and past volatility of firm-specific weekly returns $\left(S T D_{t-1}\right)$ over the fiscal year period $\mathrm{t}-1$ because Chen, Hong and Stein (2001) provide evidence that firms with high past returns and more volatile firms are more pronounced to crashes. Finally, following Hutton, Marcus, and Tehranian (2009) we include past firm size defined as the natural logarithm of market value of equity in year t-1 $\left(S I Z E_{t-1}\right)$, past market value of equity to book value of equity in year t-1 $\left(M B_{t-1}\right)$, past financial leverage defined as the total liabilities to total assets in year t-1 $\left(L E V_{t-}\right.$ 1), and past return on equity defined as income before extraordinary items to equity at year t-1 $\left(R O E_{t-1}\right)$

To address concerns for endogeneity between past crashes experiences and corporate governance, i.e., firms which have experienced stock price crashes in the past improve their governance systems to prevent such events from reoccurring, we use lagged values for the dependent variable in our regressions (see for example Harford, Mansi and Maxwell (2008)].

\section{Sample construction and descriptive statistics}

We collect weekly returns from CRSP to estimate crash measures, corporate governance measures from Corporate Library, and firm-specific financial information from Compustat. Our sample covers the period 2002-2009. Similar to prior literature, we exclude financial services firms (SIC 6000-6999), utilities (SIC 4900-4999), firm-years with price at the fiscal year-end less than $\$ 2.5$, and firm-years with less than 26 weeks of stock returns during a fiscal year. The final sample consists of 1451 firms with 6620 firm-year observations.

Table 1 presents the descriptive statistics. The mean (median) values of NCSKEW and EXTR_SIGMA are $0.115(0.060)$ and 2.674 (2.505) comparable with those reported in Kim, Li and Zhang (2011) and Bradshaw, Hutton, Marcus and Tehranian (2011). Within the 
ownership structure component of governance, the mean (median) number of blockholders is 2.524 (2.000), while institutional investors and insiders hold 79.6\% (81.6\%) and $11.2 \%$ $(5.4 \%)$, respectively. Finally, $85.9 \%(91.7 \%)$ of the directors hold stocks in the firm, which is similar to the value reported in Ashbaugh-Skaife et al. (2006) of 87\% (92\%).

\section{[Insert Table 1]}

Regarding the accounting opacity element of governance, the mean (median) values of opacity in financial reports is 0.298 (0.209). Not surprisingly, about $93.5 \%$ (100\%) of the sample has independent directors in the audit committee. Sarbanes-Oxley act of 2002 requires firms to have $100 \%$ independent audit committees. Nevertheless, there are exemptions to the rule, which explains the observed variation in audit committee independence [Xie, Davidson III and DaDalt (2003)]. Finally, about 24\% (0\%) of the firms appoint industry-specialist firms to audit financial reports.

Within the board structure and processes dimension of governance, the percentage of independent directors serving the board is $72 \%(75 \%)$. About $53.5 \%(53.3 \%)$ of the board members also serve on other boards. Finally, $68.6 \%$ of the sample the firm has a formal corporate governance policy in its mandate.

Concerning CEO incentives and power components of governance, the option and stock incentives ratio are $17.9 \%(14.3 \%)$ and $15.5 \%(6.7 \%)$, respectively. CEOs receive bonuses about $66.6 \%(38.9 \%)$ of their salary, lower than the figure reported in Kim, Li and Zhang (2011) of $81.8 \%$ (55\%). Finally, 58.6\% (100\%) of the CEOs also serve as Chairman of the board.

As far as the control variables are concerned, results show that the sample consist of large profitable firms. Specifically, the mean (median) market capitalization is 1711.285 million (1506.175) while return on equity is $9.6 \%(11.3 \%)$. As expected, the firms exhibit only moderate growth opportunities as indicated by the market to book ratio of 2.924 (2.330) 
and rely less heavily on leverage as captured by the ratio of total liabilities to total assets of $49.5 \%(50.4 \%)$. In summary, descriptive statistics in Table 1 shows that our sample is fairly representative of studies that utilize data from the same sources.

Table 2 shows Pearson (Spearman) correlation coefficients above (below) the diagonal among the crashes and corporate governance variables. Crashes are positively correlated with the percentage of institutional ownership, the financial report opacity, and the stock holdings incentives ratio. Also, crashes are negatively correlated with auditor industry expertise and with the presence of a clearly defined corporate governance policy. Notably, accounting opacity is positively related to board structure and processes, and thus complements in bridging the information gap between shareholders and managers. In addition, ownership structure is negatively related to CEO incentives and power, and therefore they are substitute mechanisms in reducing the information asymmetry problem between shareholders and managers. Finally, the correlations are not high to raise concerns for multicollinearity.

\section{[Insert Table 2]}

\section{Multivariate analysis}

We investigate the relation between corporate governance and crashes using multivariate regression analysis. Table 3 reports the results. In the first column the dependent variable is NCSKEW and in the second EXTR_SIGMA. All the regressions include year and industry dummies to control for unobserved time-invariant year and industry factors. Industry indicator variables are based on Fama and French (1997) 48 industry categories. Finally, standards errors are adjusted for clustering at the firm level to control for potential bias in the estimates when the residuals of a firm are correlated across firms [Petersen (2009)].

[Insert Table 3] 


\subsection{Corporate governance and crashes}

The results provide evidence that ownership structure, accounting opacity and board structure relate to future crashes. Specifically, there is a positive relationship between institutional ownership and crashes. This result supports the expropriation hypothesis, whereby institutions pressure management to deliver short run performance. Interestingly, the percentage of directors that hold stock in the firm is also positively related to crashes. This result casts doubt on the view that director stock ownership automatically reduces agency problems [Hambrick and Jackson (2000)]. Rather, it suggests that directors with stock ownership encourage myopic behavior [see for example Brick et al. (2006)]. Finally, there is also weak evidence that insider ownership is negatively related to crashes, consistent with the view that insider ownership aligns shareholders and manager's interests [Morck et al. (1988); McConnel and Servaes (1990].

As predicted, accounting opacity in financial reports is positively related to crashes. In addition, the percentage of independent directors serving the audit committee is negatively related to crashes. This implies that the functioning of audit committees is more effective in the presence of independent directors. Finally, firms that appoint industry-specialist audit firms display lower crashes. This finding is consistent with Dunn and Mayhew (2004) that posit that auditor expertise signals a firm's intention to provide enhanced disclosures.

In terms of board structure there is a negative relation between the presence of a governance policy and crashes. This finding suggests that in the presence of a formal, clearly defined governance policy, the manager is less able to engage in suboptimal behavior.

Contrary to the notion that equity based compensation increase crashes [ $\mathrm{Kim}, \mathrm{Li}$ and Zhang (2011)] results show no relation between CEO option and stock holdings incentives ratio. An explanation for the absence of this relation may be the fact that the period of investigation in this study is after the passage of Sarbanes-Oxley Act of 2002. Cohen, Dey 
and Lys (2005) find that opportunistic behavior of managers, related to equity-based compensation is associated with earnings management only during the period preceding SOX. Overall, our findings suggest that after SOX equity-based compensation is less likely to induce bad news hoarding, and thus crashes.

In terms of control variables, consistent with Chen, Hong, and Stein (2001) results show that crashes are positively related to the firm-specific returns and the volatility of firmspecific returns. Crashes are also positively related to return on assets. Finally, similar to Hutton et al. (2009) crashes are negatively related to firm leverage. ${ }^{5}$

\subsection{When does corporate governance really matter?}

In this section we analyze whether the relationships we uncover between governance and crashes depend on i) industry competition and ii) firm uncertainty.

Giroud and Mueller (2010) explain that the effect of corporate governance on agency problems depends on the competitiveness of the industry. When competition is high managerial slack is punished by the market, therefore the importance of corporate governance as a monitoring mechanism is reduced. We measure industry competition using the Herfindahl-Hirschman Index (HHI). The HHI is computed as the sum of squared market shares as follow:

$$
H H I_{j, t}=\sum_{i=1}^{N_{j}} S_{i, j, t}^{2}
$$

where $S_{i, j, t}$ is the market share of firm $i$ in industry $j$ in year $t$. Market share is calculated using firm sales. We estimate industry competition for each of the Fama and French 48 industry classifications. High values of HHI indicate weaker industry competition.

Our second test examines whether the uncertainty that surrounds the firms' operations plays a role. Since corporate governance helps bridge the information gap between

\footnotetext{
${ }^{5}$ To examine whether the relationships are stable (i.e., not concentrated in specific years) we have conducted the regressions on a yearly basis. We obtain the same relationships in these yearly regressions. These analysis is available from the authors upon request.
} 
shareholders and managers, it will be more important in environments of high uncertainty where this asymmetry is likely to be more pronounced [Dey, (2008)]. We measure uncertainty using the volatility of stock returns [Zhang (2006), Baker and Wurgler, (2006)]. Volatility is measured with the standard deviation of daily returns.

We break our sample in two groups based on the magnitude of the two variables at year t-1 (high or low cutting at the median), and re-run the baseline analysis of Table 3 separate for the two subsamples. This approach reveals separately the impact of corporate governance on crashes in these different regimes.

Table 4 reports the results. The first and second columns show the effects of industry competition. As expected, the effect of corporate governance on crashes are stronger in industries with low competition and in firms that exhibit high return volatility. Specifically, consistent with our previous findings, in less competitive industries crashes are positively related to the institutional ownership, the percentage of directors that hold stock in the firm and the opacity of financial reports. Interestingly, consistent with Kim, Li and Zhang (2011) there is also a positive relation between CEO option incentives ratio and crashes. The results also show a negative relation between crashes and auditor industry expertise. Within more competitive industries, crashes are positively (negatively) related to institutional ownership and the presence of formal governance policy. There is also a weaker negative relation between crashes and insider ownership and bonuses. In summary, consistent with Giroud and Mueller (2010), the effect of governance on crashes are more important in less competitive industries.

\section{[Insert Table 4]}

The third and forth column show the effect of firm uncertainty. Again as expected we find that the effect of governance on crashes are only significant in the high uncertainty environments. In particular, and consistent with our previous findings, crashes are positively 
related to institutional ownership, the percentage of directors that hold stock in the firm, and opacity of financial reports. Crashes are also negatively related to the number of blockholders, insider ownership, audit independence, auditor industry expertise and the presence of formal government policy. None of these relationships is significant among low firms with low uncertainty. Overall, the results indicate that the effect of the governance variables on crashes is solely concentrated in firms with higher uncertainty. ${ }^{6}$

\subsection{Do changes in corporate governance predict changes in crashes?}

In this section we use a dynamic, changes-based model to examine the responsiveness of crashes to changes in the corporate governance measures. This information is useful for investors because it can be used to form predictions about changes in stock price crashes, using current changes in corporate governance. To conduct the test we regress changes in crashes from $t$ - 1 to $t$ on changes in the corporate governance measures from $t$ - 2 to $t-1$, controlling for the factors discussed in section $3.3 .^{7}$

The results are shown in Table 5. In the first column crashes are measured with NCSKEW and in the second with EXTR_SIGMA. We find that an increase in the number of blockholders is associated to a reduction in crashes, which suggests that such increases imply better monitoring. ${ }^{8}$ In addition, in the first column, there is some weaker evidence that increases in insiders reduce crashes. Conversely, increases in institutional ownership are associated to increases in crashes, which signal stronger pressure for short-term performance.

\section{[Insert Table 5]}

Interestingly, we also find that changes in the variables that measure the structure of the CEO compensation are associated with increases in crashes. The positive relationship

\footnotetext{
${ }^{6}$ We obtain similar results when we use leverage and analyst forecast dispersion as proxies for uncertainty. These results are available from the authors upon request.

${ }^{7}$ The variables that are dummies (AUD_EXP, G_POL, and DUALITY) and variables with little variation across year (AUD_IND) are not differenced.

${ }^{8}$ This result is also consistent with the view that these investors make an ex ante selection choice for firms with low future crashes.
} 
between $D \_B O N U S$ and changes in crashes shows that CEO's which have received large bonuses for (presumably) improved performance have in fact engaged in activities that induced high crashes. Similarly, increases in stock based compensation (stock or option awards) also lead to higher crashes. Overall, this evidence suggest that increases in performance related compensation encourage CEOs' to engage in short run price maximization, and thus increase the incidence of crashes.

For our next test we examine whether the direction of the change in the corporate governance variables (increase or decrease) augments the relationship with changes in crashes. Specifically, we create a dummy which takes the value of 1 if the change is positive and 0 otherwise. The coefficient on the stand-alone corporate governance variables indicate the relationship between negative changes and crashes, whereas the coefficients of the interactions of the corporate governance variables with the dummy indicate whether this relationship is augmented when the change is positive. In the first column of Table 6 we measure crashes with NCSKEW and in the second with EXTR_SIGMA.

\section{[Insert Table 6]}

The results show some interesting asymmetrical relationships. We observe that changes in blockholders and board independence affect crashes only in the cases where blockholders and the percentage of board independence increases, suggesting that either an additional blockholder or an additional independent director may trigger additional monitoring but a reduction does not change the current level of monitoring. In addition, crashes increases only when institutional ownership increases, whereas decreases have not material effect. Again this relationship suggests that additional institutional investors trigger greater expropriation, whereas a reduction does not appear to change the current level.

However we do find changes in accruals (either positive or negative) induce increases in crashes. This is consistent with the nature and construction of our accruals variable, as any 
changes (whether negative or positive) captures a change in the underlying relationship between the firms accounting and its fundamentals. Thus a change in relationship could suggest either that the firm is increasing the opaqueness of their reports and therefore the likelihood of crashes or alternatively the change reflects some change in the underlying economics of the firm which in itself could also increase the crashes.

Overall the results in this section highlight that changes in the corporate governance variables are associated with changes to future stock price crashes.

\section{Conclusion}

In this study, we investigate whether corporate governance relates to future stock price crashes. Since governance can mitigate the extent to which managers can pursue strategies that are geared toward short-run price maximization, such as earnings management or overinvestment, we hypothesize that there will be a significant relationship between governance and crashes.

In our analysis we take a broad view of governance, studying how its different facets affect stock price crashes. Specifically, we use variables that capture the ownership structure of the company, its accounting opacity, its board structure and CEO incentives. In our analyses we find that a number of variables are important: crashes increase with institutional ownership, stock ownership by board members and accounting opacity, and decrease with audit expertise, audit independence and the existence of a formal governance strategy in the companies' mandate. In additional analysis we find that these effects are stronger in less competitive industries and in companies with higher uncertainty (where governance as a monitoring mechanism is more important). We also use a dynamic changes-based model to study the responsiveness of crashes to changes in crashes. This model highlights that increases to CEO performance based compensation increases crashes, which suggests that they encourage short run price maximization. 
Overall the evidence that corporate governance affects stock price crashes can help firms' design a more effective governance protocol, and investors select firms that are less prone to large price drops. 


\section{References}

Agrawal, A., Sahiba, C., 2005. Corporate governance and accounting scandals. Journal of Law and Economics 48, 371-406.

Armstrong, C., Balakrishnan, K, Cohen, D., 2012. Corporate governance and the information environment: Evidence from state antitakeover laws. Journal of Accounting and Economics, forthcoming.

Ashbaugh-Skaife, H., Collins, D., LaFond, R., 2006. The effects of corporate governance on firms' credit ratings. Journal of Accounting and Economics 4, 203-243.

Baker, M., Ruback, R.S, Wurgler, J., 2004. Behavioral Corporate Finance: A Survey. Unpublished working paper. Harvard Business School and NBER, Harvard Business School, NYU Stern School of Business and NBER.

Baker, M., Wurgler, J., 2006. Investor Sentiment and the Cross-Section of Stock Returns. The Journal of Finance 61, 1645-1680.

Ball, R., 2001. Infrastructure requirements for an economically efficient system of public financial reporting and disclosure. Brookings-Wharton Papers on Financial Services, 127169.

Beasley, M., 1996. An empirical analysis of the relation between the board of director composition and financial statement fraud. The Accounting Review 71, 443-465.

Bebchuk, L.A, Stole, L., 1993. Do short-term managerial objectives lead to under- or over-investment in long-term projects? Journal of Finance 48, 719-729.

Benmelech, E., Kandel, E., Veronesi, P., 2010. Stock-based compensation and CEO (dis)incentives. Quarterly Journal of Economics 125, 1769-1820.

Bergstresser, D., Philippon, T., 2006. CEO incentives and earnings management. Journal of Financial Economics 80, 511-529.

Bhagat, S., Black, B., 2000. Board independence and long-term performance. Unpublished working Paper. University of Colorado.

Bleck A., Liu, X., 2007. Market Transparency and the Accounting Regime. Journal of Accounting Research 45, 229-256.

Bradshaw, M. T., Hutton, A. P., Marcus, A. J., Tehranian, H., 2010. Opacity, Crashes, and the Option Smirk Curve. SSRN eLibrary.

Brick, I.E., Palmon, O., Wald, K.J, 2006. CEO compensation, director and firm performance: Evidence of cronyism? Journal of Corporate Finance 12, 403-423.

Bushee, B., 1998. The Influence of Institutional Investors on Myopic R\&D Investment Behaviour. The Accounting Review 73, 305-333. 
Bushee, B.J., 2001. Do institutional investors prefer near-term earnings over long-run value? Contemporary Accounting Research 18, 207-246.

Callen, J.L., Fang, X., 2011. Institutional Investors and Crashes: Monitoring or Expropriation? Unpublished working paper. University of Toronto, Georgia State University. SSRN eLibrary.

Chen, J., Hong, H., Stein, J. 2001. Forecasting Crashes: Trading Volume, Past Returns, and Conditional Skewness in Stock Prices. Journal of Financial Economics 61, 345-381.

Chung, K.H., Elder, J., Kim, J., 2010. Corporate governance and liquidity. Journal of Financial and Quantitative Analysis 45, 265-291.

Cohen, D.A., Dey, A., Lys, T.Z., 2005. Trends in earnings management and informativeness of earnings announcements in the pre- and post-Sarbanes Oxley periods. Unpublished working paper. University of Texas, University of Minnesota, Northwestern University,

Core, J. W., Holthausen, R. W., Larcker, D. F., 1997. Corporate governance, CEO compensation and firm performance. Mimeograph, the Wharton School, Philadelphia.

Core, J.E., Guay, W.R., Rusticus, T.O., 2006. Does Weak Governance Cause Weak Stock Returns? An Examination of Firm Operating Performance and Investors' Expectations. The Journal of Finance 6, 655-687.

Cornett, M.M., Marcus, A.J., Tehranian, H., 2008. Corporate governance and pay-forperformance: The impact of earnings management. Journal of Financial Economics 87, 357-373.

Davidson III, W.N., Xie, B., Xu, W., 2004. Market reaction to voluntary announcements of audit committee appointments: The effect of financial expertise. Journal of Accounting and Public Policy 23, 279-293.

DeFond, M.L., Hann, R.N., Hu, X., 2005. Does the market value financial expertise on audit committees of boards of directors? Journal of Accounting Research 43, 153-193.

Dey, A., 2008. Corporate governance and agency conflicts. Journal of Accounting Research 46, 1143-1181.

Dimson, E. 1979. Risk measurement when shares are subject to infrequent trading. Journal of Financial Economics 7, 197-226.

Dunn, K. A., Mayhew, B. W. 2004. Audit firm industry specialization and client disclosure quality. Review of Accounting Studies 9, 35-58.

Edmans, A., 2009. Blockholder trading, market efficiency, and managerial myopia. Journal of Finance 64, 2481-2513. 
Fahlenbranch, R., Stulz, R., 2011. Bank CEO incentives and the credit crisis. Journal of Financial Economics 99,11-26.

Fama, E.F, Jensen, M.C, 1983. Separation of ownership and control. Journal of Law and Economics 26,301-325.

Fama, E.F., French, K.R., 1997. Industry Cost of Equity. Journal of Financial Economics 43, 153-193.

Giroud, X., Mueller, H.M., 2010. Does corporate governance matter in competitive industries? Journal of Financial Economics 95, 312-331.

Gompers, P., Ishii, J., Metrick A., 2003. Corporate Governance and Equity Prices. Quarterly Journal of Economics 118, 107-155.

Graves, S., Waddock S., 1990. Institutional ownership and control: implications for longterm corporate performance. Academy of Management Executive 37, 1034-1046.

Hambrick, D. C., Jackson, E. M., 2000. Outside directors with a stake: The linchpin in improving governance. California Management Review 42, 108-127.

Harford, J., Mansi, S.A., Maxwell, W.F., 2008. Corporate governance and firm cash holdings in the US. Journal of Financial Economics 87, 535-555.

Healy P., 1985. The effect of bonus schemes on accounting decisions. Journal of Accounting \& Economics 7, 85-107.

Healy, P., Hutton, A., Palepu, K., 1999. Stock performance and intermediation changes surrounding sustained increases in disclosure. Contemporary Accounting Research 16, $485-520$.

Hermalin, B., Weisbach M., 1991. The Effects of Board Composition and Direct Incentives on Firm Performance. Financial Management 4, 101-112.

Hong, H, Stein, J.C., 2003. Differences of opinion, short-sales constraints and market crashes. Review of Financial Studies 16, 487-525.

Hutton, A., Marcus, A., Tehranian, H., 2009. Opaque financial reports and the distribution of stock returns. Journal of Financial Economics 94, 67-86.

Imhoff, E.A., 2003. Accounting Quality, Auditing, and Corporate Governance. Accounting Horizons 17, 117-128.

Jin, L., Myers, S., 2006. R2 around the world: New theory and new tests. Journal of Financial Economics 25, 257-292.

Jones, T.M, 1991. Ethical decision making by individuals in organizations: an issuecontingent model. Academy of Management Review 16, 366-395. 
Kahneman, D., Tversky, A., 1979. Prospect Theory: An Analysis of Decision Under Risk. Econometrica 47, 263-291.

Karamanou, I., Vafeas, N., 2005. The Association Between Corporate Boards, Audit Committees, and Management Earnings Forecasts: An Empirical Analysis. Journal of Accounting Research 43, 453-486.

Kedia, S., Philippon, T., 2009. The Economics of Fraudulent Accounting. Review of Financial Studies 22, 2169-2199.

Kim, J.-B., Li, Y., Zhang, L., 2011. CFOs Versus CEOs: Equity Incentives and Crashes. Journal of Financial Economics 101, 713-730.

Kim, J.-B., Zhang, L., 2010. Does Accounting Conservatism Reduce Stock Price Crashes? Unpublished working paper, City University of Hong Kong.

Klein, A., 2002. Audit committee, board characteristics and earnings management. Journal of Accounting and Economics 33, 375-400.

Klein, A., 1998. Firm performance and board committee structure. Journal of Law and Economics 41, 275- 303.

Koonce, L., McAnally, M., Mercer, M., 2005. How do investors judge the risk of derivative and non-derivative financial items? The Accounting Review 80, 221-241.

Kothari, S.P., Shu S., Wysocki, P., 2009. Do Managers Withhold Bad News? Journal of Accounting Research 47, 241-276.

Masulis, R., Wang, C., Xie, F., 2007. Corporate governance and acquirer returns. Journal of Finance 62, 1851-1889.

McConnell, J.J., Servaes, H., 1990. Additional evidence on equity ownership and corporate value. Journal of Financial Economics 27, 595-612.

McNichols, M.F., Stubben, S.R, 2008. Does earnings management affect firms' investment decisions? The Accounting Review 6, 1571-1603.

Morck, R., Shleifer, A., Vishny, R., 1988. Management ownership and market valuation: An empirical analysis. Journal of Financial Economics 20, 293-315.

Olsen, R. A., 1997. Investment Risk: The Experts Perspective. Financial Analyst Journal $53,62-66$.

Petersen, M., 2009. Estimating standard errors in finance panel data sets: comparing approaches. Review of Financial Studies 22, pp. 435-480.

Polk, C., Sapienza, P., 2009. The stock market and corporate investment: A test of catering theory. Review of Financial Studies 22, 187-217. 
Porter, M.E., 1992. Capital choice: changing the way America invests in industry. Journal of Applied Corporate Finance 5, 4-16.

Sengupta, P., 1998. Corporate disclosure quality and the cost of debt. The Accounting Review 73, 459-474.

Shivdasani, A., 1993. Board composition, ownership structure and hostile takeovers. Journal of Accounting and Economics 16, 167-198.

Shleifer, A., Vishny, R., 1997. A survey on corporate finance. Journal of Finance 52, 737-783.

Stein J., 1988. Takeover threats and managerial myopia. Journal of Political Economy 96, 61-80.

Sunder, S., 2010. Riding the accounting train: from crisis to crisis in eighty years. Presentation at the Conference on Financial Reporting, Auditing and Governance, Lehigh University, Bethlehem, PA.

Xie, B., Davidson III, W.N, DaDalt, P.J., 2003. Earnings Management and Corporate Governance: The Roles of the Board and the Audit Committee. Journal of Corporate Finance 9, 295-316.

Yermack, D., 2004. Remuneration, retention, and reputation incentives for outside directors. Journal of Finance 59, 2281-2308.

Zhang, L., 2006. Efficient estimation of stochastic volatility using noisy observations: a multi-scale approach. Bernoulli 12, 1019-1043. 


\section{Table 1}

\section{Descriptive statistics}

This table reports descriptive statistics for the dependent variables, explanatory variables and control variables. The sample consists of 1451 firms with 6620 firm-year observations during the period 2002-2009. All the variables are defined in the appendix.

\begin{tabular}{|c|c|c|c|c|c|}
\hline Variables & Mean & Median & $\begin{array}{l}\text { Standard } \\
\text { Deviation }\end{array}$ & $25^{\text {th }}$ Percentile & $75^{\text {th }}$ Percentile \\
\hline \multicolumn{6}{|c|}{ Dependent Variables } \\
\hline NCSKEW $_{\mathrm{t}}$ & 0.115 & 0.060 & 0.805 & -0.348 & 0.499 \\
\hline EXTR_SIGMA $_{t}$ & 2.674 & 2.505 & 0.768 & 2.122 & 3.069 \\
\hline \multicolumn{6}{|c|}{ Ownership Structure } \\
\hline BLOCK $_{t-1}$ & 2.524 & 2.000 & 1.541 & 1.000 & 4.000 \\
\hline$\% \mathrm{INST}_{\mathrm{t}-1}$ & 0.796 & 0.816 & 0.174 & 0.687 & 0.921 \\
\hline$\%$ INSIDER $_{\mathrm{t}-1}$ & 0.112 & 0.054 & 0.136 & 0.025 & 0.138 \\
\hline$\%$ BRD_STOCK ${ }_{t-1}$ & 0.859 & 0.917 & 0.191 & 0.778 & 1.000 \\
\hline \multicolumn{6}{|c|}{ Accounting Opacity } \\
\hline OPAQUE $_{\mathrm{t}-1}$ & 0.298 & 0.209 & 0.256 & 0.121 & 0.379 \\
\hline$\% A U D \_I N D_{t-1}$ & 0.935 & 1.000 & 0.137 & 1.000 & 1.000 \\
\hline AUD_EXPERT $T_{\mathrm{t}-1}$ & 0.240 & 0.000 & 0.427 & 0.000 & 0.000 \\
\hline \multicolumn{6}{|c|}{ Board Structure and Processes } \\
\hline$\%$ BRD_IND ${ }_{\mathrm{t}-1}$ & 0.720 & 0.750 & 0.146 & 0.625 & 0.833 \\
\hline $\mathrm{BRD}_{\mathrm{C}} \mathrm{COMP} \mathrm{t}_{\mathrm{t}-1}$ & 0.535 & 0.533 & 0.267 & 0.333 & 0.750 \\
\hline $\mathrm{GPOL}_{\mathrm{t}-1}$ & 0.686 & 1.000 & 0.464 & 0.000 & 1.000 \\
\hline \multicolumn{6}{|c|}{ CEO Incentives and Power } \\
\hline $\mathrm{INC}_{-} \mathrm{OPT} \mathrm{t}_{\mathrm{t}-1}$ & 0.179 & 0.143 & 0.145 & 0.068 & 0.257 \\
\hline INC_STC $\mathrm{t}_{\mathrm{t}-1}$ & 0.155 & 0.067 & 0.204 & 0.025 & 0.186 \\
\hline BONUS $_{t-1}$ & 0.666 & 0.389 & 0.781 & 0.000 & 1.110 \\
\hline DUALITY $_{\mathrm{t}-1}$ & 0.586 & 1.000 & 0.493 & 0.000 & 1.000 \\
\hline \multicolumn{6}{|l|}{ Control Variables } \\
\hline DTURN $_{t-1}$ & 3.313 & 2.415 & 15.146 & -3.939 & 10.578 \\
\hline RETURN $_{\mathrm{t}-1}$ & -0.111 & -0.077 & 0.098 & -0.142 & -0.044 \\
\hline $\mathrm{STD}_{\mathrm{t}-1}$ & 0.044 & 0.040 & 0.019 & 0.030 & 0.054 \\
\hline $\operatorname{SIZE}_{t-1}$ & 7.445 & 7.316 & 1.419 & 6.369 & 8.388 \\
\hline $\mathrm{MB}_{\mathrm{t}-1}$ & 2.924 & 2.330 & 1.953 & 1.583 & 3.657 \\
\hline $\mathrm{LEV}_{\mathrm{t}-1}$ & 0.495 & 0.504 & 0.197 & 0.349 & 0.631 \\
\hline $\mathrm{ROE}_{\mathrm{t}-1}$ & 0.096 & 0.113 & 0.177 & 0.045 & 0.182 \\
\hline NCSKEW $_{\mathrm{t}-1}$ & 0.123 & 0.077 & 0.678 & -0.321 & 0.513 \\
\hline NCSKEW $_{\mathrm{t}-2}$ & 0.133 & 0.085 & 0.687 & -0.313 & 0.513 \\
\hline NCSKEW $_{\mathrm{t}-3}$ & 0.143 & 0.091 & 0.670 & -0.295 & 0.516 \\
\hline
\end{tabular}


Table 2

Pearson (Spearman) correlations above (below) the diagonal among crashes and corporate governance variables

This table reports Pearson/Spearman correlations among crashes, corporate governance and control variables. The sample consists of 1451 firms with 6620 firm-year observations during the period 2002-2009. All the variables are defined in the appendix. ***, ** and *, indicate significance (two-tailed) at the $0.01,0.05$ and 0.10 level or better, respectively.

\begin{tabular}{|c|c|c|c|c|c|c|c|c|c|c|c|c|c|c|c|c|}
\hline & (1) & (2) & (3) & (4) & (5) & (6) & (7) & (8) & (9) & (10) & (11) & (12) & (13) & (14) & (15) & (16) \\
\hline \multicolumn{17}{|l|}{ Dependent Variables } \\
\hline 1.NCSKEW & 1.00 & $0.84 * * *$ & 0.01 & $0.05^{* * *}$ & 0.01 & 0.01 & $0.04^{* * * *}$ & -0.02 & $-0.03^{\text {**** }}$ & 0.00 & $\begin{array}{c}-0.01 \\
\end{array}$ & $-0.05^{* * *}$ & $0.03^{* *}$ & -0.01 & -0.01 & $\begin{array}{l}-0.02 \\
\end{array}$ \\
\hline 2.EXTR_SIGMA $A_{t}$ & 0.79 *** & 1.00 & 0.02 & $0.04 * * *$ & 0.00 & 0.00 & $0.05^{* * * *}$ & -0.01 & $-0.03^{* * * *}$ & 0.00 & 0.00 & $-0.03^{* * * *}$ & $0.02^{*}$ & -0.01 & -0.02 & $-0.03 * *$ \\
\hline \multicolumn{17}{|l|}{ Ownership Structure } \\
\hline 3.BLOCK $\mathrm{t}_{\mathrm{t}-1}$ & 0.00 & 0.02 & 1.00 & $0.55^{* * * *}$ & $-0.04 * * *$ & $-0.04^{* * * *}$ & $0.05^{* * * *}$ & $0.06^{* * *}$ & $-0.04^{* * * *}$ & $0.11^{* * * *}$ & -0.14 **** & $0.05^{* * * *}$ & $-0.13^{* * * *}$ & $-0.13^{* * *}$ & $-0.19^{* * * *}$ & $-0.07^{* * * *}$ \\
\hline $4 . \% \mathrm{INST}_{\mathrm{t}-1}$ & $0.04^{* * * *}$ & $0.04^{* * * *}$ & $0.55^{* * * *}$ & 1.00 & $-0.27 * * *$ & $-0.02^{*}$ & $0.06^{* * * *}$ & $0.08^{* * * *}$ & -0.01 & $0.21^{* * *}$ & $-0.07^{* * * * *}$ & $0.20^{* * * *}$ & $0.11^{* * * *}$ & $-0.13^{* * * *}$ & $-0.07^{* * * *}$ & -0.02 \\
\hline $5 . \%$ INSIDER $_{t-1}$ & 0.01 & 0.02 & $0.04^{* * * *}$ & $-0.20^{* * * *}$ & 1.00 & $-0.09 * * *$ & $\begin{array}{c}-0.01 \\
\end{array}$ & $-0.05 * * *$ & $-0.04^{* * * * *}$ & $-0.33 * * *$ & $-0.10^{* * * * *}$ & $-0.30^{* * * *}$ & $-0.12^{* * * * *}$ & $0.30^{* * *}$ & $-0.06^{* * * *}$ & $-0.04 * * *$ \\
\hline 6.\%BRD_STOCK $\mathrm{t}_{\mathrm{t}-1}$ & 0.02 & 0.01 & $-0.04 * * *$ & $-0.02^{*}$ & $-0.16^{* * * *}$ & 1.00 & $-0.09 * * *$ & 0.02 & $0.07 * * *$ & $0.11^{* * *}$ & $0.07 * * *$ & $0.15^{* * *}$ & -0.01 & $-0.05^{* * * *}$ & $0.04 * * *$ & $0.09^{* * * *}$ \\
\hline \multicolumn{17}{|l|}{ Accounting Opacity } \\
\hline 7.OPAQUE $\mathrm{t}_{\mathrm{t}-1}$ & $0.03^{* * * *}$ & $0.05^{* * * *}$ & $0.05^{* * * *}$ & $0.06^{* * *}$ & 0.01 & $-0.12^{* * * *}$ & 1.00 & -0.02 & $-0.08 * * *$ & -0.01 & $-0.09 * * *$ & $-0.03 * * *$ & $0.04 * * *$ & $0.03 * * *$ & $-0.08 * * *$ & $-0.06 * * *$ \\
\hline 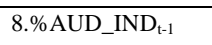 & -0.02 & 0.00 & $0.06^{\text {**** }}$ & $0.07^{* * *}$ & $-0.06^{* * * *}$ & $0.03^{* *}$ & $\begin{array}{c}-0.01 \\
\end{array}$ & 1.00 & $\begin{array}{c}-0.01 \\
\end{array}$ & $0.52^{* * *}$ & 0.00 & $0.04 * * *$ & 0.00 & $-0.05^{* * * *}$ & $-0.03^{* *}$ & 0.02 \\
\hline 9.AUD_EXPERT $T_{t-1}$ & $-0.03 * * *$ & $-0.03^{* * * *}$ & $-0.04 * * *$ & -0.02 & $-0.09 * * *$ & $0.05^{* * *}$ & $-0.11 * * *$ & -0.01 & 1.00 & $0.06^{* * *}$ & $0.07 * * *$ & $0.08^{* * *}$ & $0.05 * * *$ & $-0.02^{*}$ & $0.05 * * *$ & 0.03 ** \\
\hline \multicolumn{17}{|c|}{ Board Structure and Processes } \\
\hline $10 . \%$ BRD_IND $_{\mathrm{t}-1}$ & -0.01 & 0.01 & $0.09^{* * * *}$ & $0.18^{* * *}$ & $-0.39^{* * * *}$ & $0.15^{* * *}$ & $-0.02 *$ & $0.44 * * *$ & $0.07 * * *$ & 1.00 & $0.12 * * *$ & $0.20^{* * *}$ & $0.10^{* * *}$ & $-0.17 * * *$ & $-0.02^{* * *}$ & $0.12^{* * * *}$ \\
\hline 11.BRD_COMP & -0.01 & 0.00 & $-0.14 * * *$ & $-0.09 * * *$ & $-0.15^{* * * *}$ & $0.07^{* * *}$ & $-0.09 * * *$ & 0.01 & $0.06 * * *$ & $0.12^{* * *}$ & 1.00 & $0.11^{* * *}$ & $0.14 * * *$ & $-0.09 * * *$ & 0.27 *** & $0.12^{* * * *}$ \\
\hline $12 . \mathrm{GPOL}_{\mathrm{t}-1}$ & -0.05 *** & $-0.03^{* * *}$ & $0.04^{* * * *}$ & $0.19^{* * *}$ & $-0.34 * * *$ & $0.16^{* * * *}$ & $-0.06 * * *$ & $0.03^{* *}$ & $0.08^{* * * *}$ & $0.19^{* * * *}$ & $0.10^{\text {**** }}$ & 1.00 & $0.12^{* * * *}$ & $-0.08^{* * * *}$ & $0.06^{* * * *}$ & $0.03 * *$ \\
\hline \multicolumn{17}{|c|}{ CEO Incentives and Power } \\
\hline 13.INC_OPT & $0.03^{* * * *}$ & $0.03^{* * * *}$ & $-0.12 * * *$ & $0.12 * * *$ & $-0.14 * * *$ & -0.01 & $0.02 *$ & 0.01 & $0.06 * * *$ & $0.12 * * *$ & $0.17^{* * * *}$ & $0.12 * * *$ & 1.00 & $0.18^{* * *}$ & $-0.10^{* * * *}$ & $0.10^{* * * *}$ \\
\hline 14.INC_STC ${ }_{t-1}$ & 0.00 & -0.01 & $-0.11 * * *$ & $-0.03 * *$ & $0.16^{* * * *}$ & $0.04 * * *$ & 0.01 & $-0.03 * *$ & 0.00 & $-0.08^{* * * *}$ & $-0.08 * * *$ & 0.01 & $0.2 * * *$ & 1.00 & $-0.14 * * *$ & $0.17 * * *$ \\
\hline 15. BONUS $_{\mathrm{t}-1}$ & -0.01 & -0.02 & $-0.18^{* * * *}$ & $-0.09^{* * * *}$ & $-0.05 * * *$ & 0.02 & $-0.07^{* * *}$ & $-0.02 *$ & $0.05 * * *$ & $-0.04 * * *$ & $0.30^{* * * *}$ & 0.01 & $-0.09 * * *$ & $-0.18^{* * * *}$ & 1.00 & $0.12 * * *$ \\
\hline 16.DUALITY ${ }_{\mathrm{t}-1}$ & -0.01 & $-0.02 *$ & $-0.07 * * *$ & $-0.03^{* * * *}$ & $-0.09 * * *$ & $0.11^{* * *}$ & $-0.07 * * *$ & $0.02 *$ & $0.03 * * *$ & $0.14^{* * *}$ & $0.12 * * *$ & $0.03^{* * *}$ & $0.10^{\text {**** }}$ & $0.19^{* * *}$ & $0.10^{* * * *}$ & 1.00 \\
\hline
\end{tabular}


Table 3

Corporate governance and crashes

This table reports ordinary least squares coefficient estimates with standard errors adjusted for clustering at the firm level. The sample consists of 1451 firms with 6620 firm-year observations during the period 2002-2009. All the variables are defined in the appendix. t-statistic is in parenthesis below the coefficient. ***, ** and *, indicate significance (two-tailed) at the $0.01,0.05$ and 0.10 level or better, respectively.

\begin{tabular}{|c|c|c|c|}
\hline Variables & Predicted Sign & NCSKEW & EXTR_SIGMA \\
\hline \multicolumn{4}{|l|}{ Ownership Structure } \\
\hline $\mathrm{BLOCK}_{\mathrm{t}-1}$ & $?$ & $\begin{array}{l}-0.011 \\
(-1.24)\end{array}$ & $\begin{array}{l}-0.012 \\
(-1.47)\end{array}$ \\
\hline$\% \mathrm{INST}_{\mathrm{t}-1}$ & $?$ & $\begin{array}{c}0.323 * * * \\
(4.17)\end{array}$ & $\begin{array}{c}0.259 * * * \\
(3.44)\end{array}$ \\
\hline$\%$ INSIDER $_{\mathrm{t}-1}$ & - & $\begin{array}{l}-0.104 \\
(-1.20)\end{array}$ & $\begin{array}{c}-0.143^{*} \\
(-1.66)\end{array}$ \\
\hline$\%$ BRD_STOCK & + & $\begin{array}{c}0.096^{*} \\
(1.87)\end{array}$ & $\begin{array}{c}0.130 * * \\
(2.55)\end{array}$ \\
\hline \multicolumn{4}{|l|}{ Accounting Opacity } \\
\hline OPAQUE $_{\mathrm{t}-1}$ & + & $\begin{array}{c}0.122 * * \\
(2.45)\end{array}$ & $\begin{array}{c}0.099 * * \\
(2.10)\end{array}$ \\
\hline$\% A U D \_I N D_{t-1}$ & - & $\begin{array}{c}-0.172 * * \\
(-2.02)\end{array}$ & $\begin{array}{l}-0.111 \\
(-1.32)\end{array}$ \\
\hline AUD_EXPERT $T_{t-1}$ & - & $\begin{array}{c}-0.056^{* * *} \\
(-2.23)\end{array}$ & $\begin{array}{l}-0.047 * \\
(-1.95)\end{array}$ \\
\hline \multicolumn{4}{|c|}{ Board Structure and Processes } \\
\hline$\%$ BRD_IND ${ }_{\mathrm{t}-1}$ & - & $\begin{array}{l}0.053 \\
(0.57)\end{array}$ & $\begin{array}{l}0.046 \\
(0.52)\end{array}$ \\
\hline BRD_COMP ${ }_{\mathrm{t}-1}$ & - & $\begin{array}{l}0.015 \\
(0.32)\end{array}$ & $\begin{array}{l}0.029 \\
(0.63)\end{array}$ \\
\hline GPOL $_{t-1}$ & - & $\begin{array}{c}-0.053^{*} \\
(-1.84)\end{array}$ & $\begin{array}{c}-0.052^{*} \\
(-1.90)\end{array}$ \\
\hline \multicolumn{4}{|c|}{ CEO Incentives and Power } \\
\hline $\mathrm{INC}_{-} \mathrm{OPT}_{\mathrm{t}-1}$ & + & $\begin{array}{l}0.069 \\
(0.82)\end{array}$ & $\begin{array}{l}0.058 \\
(0.71)\end{array}$ \\
\hline $\mathrm{INC}_{-} \mathrm{STC}_{\mathrm{t}-1}$ & - & $\begin{array}{l}-0.039 \\
(-0.73)\end{array}$ & $\begin{array}{l}-0.010 \\
(-0.21)\end{array}$ \\
\hline BONUS $_{\mathrm{t}-1}$ & + & $\begin{array}{l}-0.010 \\
(-0.65)\end{array}$ & $\begin{array}{l}-0.011 \\
(-0.72)\end{array}$ \\
\hline $\operatorname{DUALITY}_{\mathrm{t}-1}$ & + & $\begin{array}{l}-0.018 \\
(-0.83)\end{array}$ & $\begin{array}{l}-0.022 \\
(-1.07)\end{array}$ \\
\hline \multicolumn{4}{|l|}{ Control Variables } \\
\hline DTURN $_{\mathrm{t}-1}$ & + & $\begin{array}{l}0.001 \\
(1.20)\end{array}$ & $\begin{array}{l}0.001 \\
(1.55)\end{array}$ \\
\hline RETURN $_{t-1}$ & + & $\begin{array}{c}0.949^{*} \\
(1.79)\end{array}$ & $\begin{array}{l}0.315 \\
(0.61)\end{array}$ \\
\hline $\mathrm{STD}_{\mathrm{t}-1}$ & + & $\begin{array}{l}5.631^{*} \\
(1.92)\end{array}$ & $\begin{array}{l}1.644 \\
(0.57)\end{array}$ \\
\hline $\mathrm{SIZE}_{\mathrm{t}-1}$ & - & $\begin{array}{l}-0.005 \\
(-0.44)\end{array}$ & $\begin{array}{c}-0.025 * * \\
(-2.36)\end{array}$ \\
\hline $\mathrm{MB}_{\mathrm{t}-1}$ & + & $\begin{array}{l}0.004 \\
(0.54)\end{array}$ & $\begin{array}{l}-0.001 \\
(-0.21)\end{array}$ \\
\hline $\mathrm{LEV}_{\mathrm{t}-1}$ & - & $\begin{array}{c}-0.183 * * * \\
(-2.60)\end{array}$ & $\begin{array}{l}-0.074 \\
(-1.17)\end{array}$ \\
\hline $\mathrm{ROE}_{\mathrm{t}-1}$ & - & $\begin{array}{c}0.143^{* *} \\
(2.01)\end{array}$ & $\begin{array}{c}0.125^{*} \\
(1.94)\end{array}$ \\
\hline DEPENDENT $_{\mathrm{t}-1}$ & $?$ & $\begin{array}{l}-0.002 \\
(-0.11)\end{array}$ & $\begin{array}{l}0.007 \\
(0.56)\end{array}$ \\
\hline DEPENDENT $_{\mathrm{t}-2}$ & $?$ & $\begin{array}{l}0.020 \\
(1.31)\end{array}$ & $\begin{array}{c}0.028 * * \\
(2.08)\end{array}$ \\
\hline DEPENDENT $_{\mathrm{t}-3}$ & ? & $\begin{array}{l}0.008 \\
(0.51)\end{array}$ & $\begin{array}{l}0.016 \\
(1.25)\end{array}$ \\
\hline Intercept & & Yes & Yes \\
\hline Year fixed effects & & Yes & Yes \\
\hline Industry fixed effects & & Yes & Yes \\
\hline Adj. $R^{2}$ & & 0.021 & 0.023 \\
\hline
\end{tabular}


Table 4

Corporate governance and crashes: the effect of industry competition and firm uncertainty

This table reports ordinary least squares coefficient estimates of yearly regressions with standard errors adjusted for clustering at the firm level. The sample consists of 1451 firms with 6620 firm-year observations during the period 2002-2009. All the variables are defined in the appendix. The top value in each cell refers to NCSKEW and the bottom value to EXTR_SIGMA. $* * * * *$ and $*$, indicate significance (two-tailed) at the $0.01,0.05$ and 0.10 level or better, respectively.

\begin{tabular}{|c|c|c|c|c|c|}
\hline \multirow[t]{2}{*}{ Variables } & \multirow[t]{2}{*}{ Predicted Sign } & \multicolumn{2}{|c|}{ Industry Competition } & \multicolumn{2}{|c|}{ Return Volatility } \\
\hline & & High & Low & High & Low \\
\hline \multicolumn{2}{|c|}{ Degree of Information Asymmetry } & LOW & HIGH & HIGH & LOW \\
\hline \multicolumn{6}{|l|}{ Ownership Structure } \\
\hline \multirow[t]{2}{*}{$\mathrm{BLOCK}_{\mathrm{t}-1}$} & $?$ & -0.005 & -0.016 & $-0.024^{*}$ & -0.006 \\
\hline & & -0.012 & -0.011 & $-0.024 * *$ & -0.008 \\
\hline \multirow[t]{2}{*}{$\% \mathrm{INST}_{\mathrm{t}-1}$} & $?$ & $0.256^{* *}$ & $0.390 * * *$ & $0.400^{* * *}$ & 0.119 \\
\hline & & $0.245^{* *}$ & $0.270^{* * *}$ & $0.308 * * *$ & 0.101 \\
\hline \multirow[t]{2}{*}{$\%$ INSIDER $_{\mathrm{t}-1}$} & - & $-0.231^{*}$ & 0.021 & $-0.312 * *$ & 0.020 \\
\hline & & $-0.210^{*}$ & -0.101 & $-0.349 * *$ & -0.024 \\
\hline \multirow[t]{2}{*}{$\%$ BRD_STOCK ${ }_{\mathrm{t}-1}$} & + & 0.053 & $0.154 * *$ & $0.162 * *$ & 0.060 \\
\hline & & 0.100 & $0.161 * *$ & $0.191 * * *$ & 0.095 \\
\hline \multicolumn{6}{|l|}{ Accounting Opacity } \\
\hline \multirow[t]{2}{*}{ OPAQUE $_{\mathrm{t}-1}$} & + & 0.072 & $0.227 * * *$ & $0.138 * *$ & 0.029 \\
\hline & & 0.061 & $0.205^{* *}$ & $0.133 * *$ & 0.021 \\
\hline \multirow[t]{2}{*}{$\% A U D \_I N D_{t-1}$} & - & -0.174 & -0.166 & $-0.366^{* * *}$ & -0.027 \\
\hline & & -0.067 & -0.179 & $-0.304 * *$ & 0.050 \\
\hline \multirow{2}{*}{ AUD_EXPERT $T_{\mathrm{t}-1}$} & - & -0.030 & $-0.078 * *$ & $-0.091 * *$ & -0.011 \\
\hline & & -0.026 & $-0.067 * *$ & $-0.109 * * *$ & 0.017 \\
\hline \multirow{3}{*}{$\begin{array}{l}\text { Board Structure } \\
\text { \%BRD_IND }\end{array}$} & and & & & & \\
\hline & - & 0.067 & 0.024 & 0.078 & 0.023 \\
\hline & & 0.080 & 0.023 & 0.079 & -0.012 \\
\hline \multirow{2}{*}{ BRD_COMP $_{\mathrm{t}-1}$} & - & 0.071 & -0.056 & 0.008 & -0.004 \\
\hline & & 0.014 & 0.045 & 0.038 & -0.020 \\
\hline \multirow[t]{2}{*}{$\mathrm{GPOL}_{\mathrm{t}-1}$} & - & $-0.073^{*}$ & -0.017 & $-0.091 * *$ & 0.014 \\
\hline & & $-0.084^{* *}$ & 0.001 & $-0.087 * *$ & 0.006 \\
\hline \multicolumn{6}{|c|}{ CEO Incentives and Power } \\
\hline \multirow[t]{2}{*}{$\mathrm{INC}_{-} \mathrm{OPT}_{\mathrm{t}-1}$} & + & -0.086 & $0.270 * *$ & 0.207 & -0.051 \\
\hline & & -0.119 & $0.294 * * *$ & 0.168 & -0.044 \\
\hline \multirow[t]{2}{*}{ INC_STC $\mathrm{t}_{\mathrm{t}-1}$} & - & -0.032 & -0.051 & -0.034 & -0.078 \\
\hline & & -0.006 & -0.015 & 0.003 & -0.053 \\
\hline \multirow[t]{2}{*}{ BONUS $_{\mathrm{t}-1}$} & + & -0.033 & 0.017 & 0.014 & -0.032 \\
\hline & & $-0.049 * *$ & 0.033 & 0.022 & $-0.037 *$ \\
\hline \multirow[t]{2}{*}{ DUALITY $_{\mathrm{t}-1}$} & + & -0.018 & -0.024 & -0.018 & -0.030 \\
\hline & & -0.021 & -0.032 & -0.029 & -0.017 \\
\hline \multicolumn{2}{|l|}{ Intercept } & Yes & Yes & Yes & Yes \\
\hline \multicolumn{2}{|l|}{ Control Variables } & Yes & Yes & Yes & Yes \\
\hline \multicolumn{2}{|l|}{ Year fixed effects } & Yes & Yes & Yes & Yes \\
\hline Industry fixed effects & & Yes & Yes & Yes & Yes \\
\hline No of obs. & & 3309 & 3311 & 3029 & 3028 \\
\hline & & 3309 & 3311 & 3029 & 3028 \\
\hline Adj. $\mathrm{R}^{2}$ & & 0.022 & 0.020 & 0.038 & 0.003 \\
\hline & & 0.021 & 0.029 & 0.042 & 0.009 \\
\hline
\end{tabular}


Table 5

Responsiveness of crashes on to changes in corporate governance

This table reports ordinary least squares coefficient estimates with standard errors adjusted for clustering at the firm level. The sample consists of 1451 firms with 6620 firm-year observations during the period 2002-2009. All the variables are defined in the appendix. t-statistic is in parenthesis below the coefficient. ***, ** and *, indicate significance (two-tailed) at the $0.01,0.05$ and 0.10 level or better, respectively.

\begin{tabular}{|c|c|c|}
\hline Variables & NCSKEW & $\overline{\text { EXTR_SIGMA }}$ \\
\hline \multicolumn{3}{|l|}{ Ownership Structure } \\
\hline D_BLOCK $\mathrm{t}_{\mathrm{t}-1}$ & $\begin{array}{c}-0.039 * * * \\
(-2.55)\end{array}$ & $\begin{array}{c}-0.043 * * * \\
(-2.96)\end{array}$ \\
\hline$D_{-} \% \mathrm{INST}_{\mathrm{t}-1}$ & $\begin{array}{c}0.799 * * * \\
(3.24)\end{array}$ & $\begin{array}{c}0.735 * * * \\
(3.25)\end{array}$ \\
\hline D_\%INSIDER ${ }_{t-1}$ & $\begin{array}{l}-0.642^{*} \\
(-1.73)\end{array}$ & $\begin{array}{l}-0.369 \\
(-1.05)\end{array}$ \\
\hline D_\%BRD_STOCK & $\begin{array}{l}0.123 \\
(0.83)\end{array}$ & $\begin{array}{l}0.176 \\
(1.22)\end{array}$ \\
\hline \multicolumn{3}{|l|}{ Accounting Opacity } \\
\hline D_OPAQUE ${ }_{\mathrm{t}-1}$ & $\begin{array}{l}0.075 \\
(0.61)\end{array}$ & $\begin{array}{l}0.027 \\
(0.23)\end{array}$ \\
\hline$\% A U D \_I N D_{t-1}$ & $\begin{array}{l}0.030 \\
(0.32)\end{array}$ & $\begin{array}{l}0.038 \\
(0.39)\end{array}$ \\
\hline AUD_EXPERT $_{\mathrm{t}-1}$ & $\begin{array}{l}-0.018 \\
(-0.63)\end{array}$ & $\begin{array}{l}-0.016 \\
(-0.60)\end{array}$ \\
\hline \multicolumn{3}{|c|}{ Board Structure and Processes } \\
\hline D_\%BRD_IND ${ }_{\mathrm{t}-1}$ & $\begin{array}{l}-0.049 \\
(-0.21)\end{array}$ & $\begin{array}{l}-0.067 \\
(-0.32)\end{array}$ \\
\hline D_BRD_COMP ${ }_{\mathrm{t}-1}$ & $\begin{array}{l}-0.012 \\
(-0.09)\end{array}$ & $\begin{array}{l}-0.041 \\
(-0.34)\end{array}$ \\
\hline $\mathrm{GPOL}_{\mathrm{t}-1}$ & $\begin{array}{l}-0.052 \\
(-1.58)\end{array}$ & $\begin{array}{c}-0.072 * * \\
(-2.18)\end{array}$ \\
\hline \multicolumn{3}{|c|}{ CEO Incentives and Power } \\
\hline D_INC_OPT & $\begin{array}{c}1.022 * * * \\
(3.76)\end{array}$ & $\begin{array}{l}0.808 * * * \\
(3.13)\end{array}$ \\
\hline D_INC_STC & $\begin{array}{c}0.773 * * * \\
(2.82)\end{array}$ & $\begin{array}{l}0.322 \\
(1.27)\end{array}$ \\
\hline D_BONUS ${ }_{\mathrm{t}-1}$ & $\begin{array}{l}0.180 * * * \\
(5.50)\end{array}$ & $\begin{array}{c}0.106 * * * \\
(3.30)\end{array}$ \\
\hline DUALITY $_{\mathrm{t}-1}$ & $\begin{array}{l}-0.021 \\
(-0.89)\end{array}$ & $\begin{array}{l}-0.028 \\
(-1.18)\end{array}$ \\
\hline Crash_risk $\mathrm{t}_{-2}$ & $\begin{array}{l}0.0198 \\
(0.76)\end{array}$ & $\begin{array}{l}0.021 \\
(1.00)\end{array}$ \\
\hline Intercept & Yes & Yes \\
\hline Control Variables & Yes & Yes \\
\hline Year fixed effects & Yes & Yes \\
\hline $\begin{array}{l}\text { Industry fixed effects } \\
\text { Adj. } R^{2}\end{array}$ & Yes & Yes \\
\hline
\end{tabular}




\section{Table 6}

\section{Responsiveness of crashes to positive and negative changes in corporate governance}

This table reports ordinary least squares coefficient estimates with standard errors adjusted for clustering at the firm level. The sample consists of 1451 firms with 6620 firm-year observations during the period 2002-2009. All the variables are defined in the appendix. t-statistic is in parenthesis below the coefficient. ***, ** and *, indicate significance (two-tailed) at the $0.01,0.05$ and 0.10 level or better, respectively.

\begin{tabular}{|c|c|c|}
\hline Variables & NCSKEW & EXTR_SIGMA \\
\hline \multicolumn{3}{|l|}{ Ownership Structure } \\
\hline$D_{-}$BLOCK $_{\mathrm{t}-1}$ & 0.018 & -0.007 \\
\hline P_D_BLOCK & $-0.098 * *$ & $-0.061^{*}$ \\
\hline$D_{-} \% I_{N S T} T_{t-1}$ & 0.178 & -0.256 \\
\hline P_D_\%INST $T_{t-1}$ & 0.971 & $1.543^{* *}$ \\
\hline D_\%INSIDER $\mathrm{t}_{\mathrm{t}-1}$ & -0.534 & -0.247 \\
\hline P_D_\%INSIDER ${ }_{t-1}$ & -0.929 & -1.495 \\
\hline D_\%BRD_STOCK $K_{t-1}$ & 0.017 & 0.016 \\
\hline P_D_\%BRD_STOCK $\mathrm{K}_{\mathrm{t}-1}$ & 0.20 & 0.272 \\
\hline \multicolumn{3}{|l|}{ Accounting Opacity } \\
\hline$D_{\text {D_OPAQUE }}$ t-1 & -0.536 & $-0.512 * *$ \\
\hline P_D_OPAQUE $E_{t-1}$ & $0.985^{* *}$ & $0.871^{* *}$ \\
\hline$\% A U D \_I N D_{t-1}$ & -0.014 & -0.002 \\
\hline AUD_EXPERT $T_{t-1}$ & -0.019 & -0.017 \\
\hline \multicolumn{3}{|c|}{ Board Structure and Processes } \\
\hline D_\%BRD_IND & 0.238 & 0.496 \\
\hline P_D_\%BRD_IND & -0.511 & $-0.955^{*}$ \\
\hline D_BRD_COMP ${ }_{\mathrm{t}-1}$ & -0.160 & -0.103 \\
\hline P_D_BRD_COMP $\mathrm{t}_{\mathrm{t}-1}$ & 0.323 & 0.142 \\
\hline $\mathrm{GPOL}_{\mathrm{t}-1}$ & -0.050 & $-0.072^{* *}$ \\
\hline \multicolumn{3}{|c|}{ CEO Incentives and Power } \\
\hline D_INC_OPT $\mathrm{t}-1_{1}$ & $0.830 * *$ & 0.456 \\
\hline P_D_INC_OPT $\mathrm{t}_{\mathrm{t}-1}$ & 0.440 & 0.805 \\
\hline D_INC_STC C & $0.660^{*}$ & 0.385 \\
\hline P_D_INC_STC C & 0.339 & -0.115 \\
\hline D_BONUS $_{\mathrm{t}-1}$ & $0.173 * * *$ & $0.105^{* *}$ \\
\hline P_D_BONUS $\mathrm{t}_{\mathrm{t}-1}$ & 0.040 & 0.021 \\
\hline DUALITY $_{\mathrm{t}-1}$ & -0.021 & -0.027 \\
\hline NCSKEW $_{\mathrm{t}-2}$ & 0.023 & \\
\hline EXTR_SIGMA ${ }_{t-2}$ & & 0.023 \\
\hline Intercept & Yes & Yes \\
\hline Control Variables & Yes & Yes \\
\hline Year fixed effects & Yes & Yes \\
\hline Industry fixed effects & Yes & Yes \\
\hline Adj. $R^{2}$ & 0.042 & 0.039 \\
\hline
\end{tabular}




\section{Appendix: Definitions of Variable}

\section{Dependent Variables:}

NCSKEW

EXTR_SIGMA

CRASH

DUVOL

\section{Ownership Structure:}

Negative of the third moment of firm-specific weekly returns for each firm and year divided by the standard deviation of firm-specific weekly returns raised to the third power

Negative of the worst deviation of firm-specific weekly returns from the average firm-specific weekly return divided by the standard deviation of firm-specific weekly returns

An indicator variable that equals one when a firm experiences at least one crash week during the fiscal year, and zero otherwise

Log of the ratio of the standard deviation of the "down weeks" over the standard deviation of the "up weeks"

\begin{tabular}{ll}
\hline BLOCK & $\begin{array}{l}\text { Number of outside blockholders that owned at } \\
\text { least } 5 \% \text { of a firm }\end{array}$ \\
\%INST & $\begin{array}{l}\text { Percentage of shares held by institutional } \\
\text { investors }\end{array}$ \\
\%INSIDER & Percentage of shares held by officers or directors \\
\%BRD_STOCK & Percentage of directors hold stock in the firm \\
Accounting Opacity: & $\begin{array}{l}\text { Three-year moving sum of the absolute } \\
\text { discretionary accruals estimated from a modified } \\
\text { Jones (1991) model }\end{array}$ \\
\hline OPAQUE & $\begin{array}{l}\text { Percentage of outside independent directors in the } \\
\text { audit committee }\end{array}$ \\
DuUD_EXPERT & $\begin{array}{l}\text { Dummy variable that equals one when the audit } \\
\text { firm of a particular firm has more than one third } \\
\text { of market share of total sales within an industry, } \\
\text { and zero otherwise }\end{array}$
\end{tabular}

Board Structure and Processes:

\begin{tabular}{ll}
\hline \%BRD_IND & Percentage of outside directors serving the board \\
BRD_COMP & $\begin{array}{l}\text { Percentage of directors that also serve on boards } \\
\text { of other firms }\end{array}$
\end{tabular}


GPOL

Dummy variable that equals one if corporate strategy exists, and zero otherwise

CEO Incentives and Power:

INC_OPT

INC_STC

BONUS

DUALITY
Option holdings incentives ratio estimated as in Bergstresser and Philippon (2006)

Stock holdings incentives ratio estimated as in Bergstresser and Philippon (2006)

CEOs bonus scaled by salary

Dummy variable that equals one when the positions of the CEO and the chairman of the board are held by the same person, and zero otherwise

\section{Control Variables:}

\begin{tabular}{ll}
\hline DTURN & Detrended average weekly stock trading volume \\
RETURN & Past average firm-specific weekly returns \\
STD & Past volatility of firm-specific weekly returns \\
SIZE & Natural logarithm of market value of equity \\
MB & Market value of equity to book value of equity \\
LEV & Total liabilities to total assets \\
ROE & Income before extraordinary items to equity
\end{tabular}

